\title{
An Analysis on the Use of Educational Social Networking Sites in the Course Activities of Geography Department Students: Edmodo Sample ${ }^{\mathrm{i}}$
}

\author{
Emine Teyfur ${ }^{1}$, Adem Özkan,"*, Mehmet Teyfur ${ }^{3}$ \\ ${ }^{1}$ Faculty of Science and Literature, Ağrı İbrahim Çeçen University, Turkey \\ ${ }^{2}$ Vocational High School, Ağrı İbrahim Çeçen University, Turkey \\ ${ }^{3}$ Faculty of Education, Ağrı İbrahim Çeçen University, Turkey
}

Copyright $\bigcirc 2017$ by authors, all rights reserved. Authors agree that this article remains permanently open access under the terms of the Creative Commons Attribution License 4.0 International License

\begin{abstract}
The aim of this study was to examine the views of the students of Geography Department on the use of ESNS Edmodo in the course activities. Sequential explanatory design in mixed methods research designs was used in the study. This study was conducted with a total of 41 second grade students who take Europe Geography class and study in the Department of Geography, Faculty of Science and Letters, İbrahim Çeçen University of Ağrı during the spring semester of 2016-2017. The study lasted a total of seven weeks, of which two weeks are pilot week and another five weeks are implementation week. Based on the findings obtained through the study, it was found that the site Edmodo is useful in computer environment, but difficulties are experienced in some of its applications in mobile applications. It was also found that Edmodo enhances interclass student-student interaction. It was observed that these results are in parallel with the studies conducted in the field.
\end{abstract}

Keywords Educational Social Networking, Geography Education, ESNS, Edmodo

\section{Introduction}

Throughout human history, the need for learning, which is one of the most important needs of people, has been tried to be solved in parallel with the technology of the present time with different techniques and methods until today. Nowadays, the developing computer and internet technologies have been used effectively to solve this need. It is seen that the field in which these technologies are used the most is the distance education technologies.

Distance education systems are systems that allow teachers and students to participate in learning activities even when they are in different environments. Thanks to these features, the distance education has become the preferred learning method today [1]. Distance education activities were carried out through different ways in the past and have started to be carried out in electronic environments with the spread of computer and internet technologies. This has led to emergence of e-learning concept. Along with the concept of e-learning, the organization of e-learning process and interaction and communication problems in the concept of e-learning have emerged at the point of importance of interaction and communication in presenting content and education. In this context, Teaching Management Systems (TMS) has been developed in order to solve the problems of organization of the e-learning process and presentation of the content TMSs are web-based environments in which students can interact with teachers and other students while learning asynchronously and synchronously [1]. Duran, Önal, and Kurtulus [2] found that the advantages of the TMSs are that they are easy to use because they do not require much computer knowledge, they have different language options, they are suitable for educational rules, they can record, they support collaborative learning, and the study field can be arranged according to the will of the user. After examining the studies on TMSs, it is seen that besides these advantages, there are also disadvantages of TMSs. Although they are free, they can be high cost [2], they lack usefulness of discussion and interpretation [3] and they have limitations in interaction and communication and they are inadequate in the levels of social readiness in this context.

\subsection{The Importance of the Study}

Social Networking Sites (SNS), a product of Web 2.0 technology, started to be used in distance education management in order to eliminate the limitations of TMS, which are mainly used in the management of distance 
education systems, such as communication and interaction. SNSs are the systems in which the individuals can create profiles in a registered system which are open or semi-open to others, through which they can share and can see what others share and see their circle of friends, can share the activities and likes of the people in online communities and can send messages through the network, can create discussion groups, and can send videos and voice mails [4] Today, students are able to meet each other, create communities and communicate with each other through SNSs [5]. Considering the discussion groups in which students voluntarily participate through the SNSs, it has been suggested that SNSs can be used for training [6].

After the features of the SASs are examined, it is seen that these features are parallel with the views of the social cognitive learning theory and the constructivist learning theory on the learning process [7]. These strong features are that it supports synchronous communication and data to share the teachers and students' need, to establish interpersonal communication, to establish communities, to share multimedia and to collaborate [8]. It is also recommended for students who do not have a one-to-one connection with teachers as it creates a community feeling in an online setting [9]. The excessive number of students in formal education leads to failure of the activities such as evaluation of education [10] and feedback to this evaluation [11]. This has negative impacts on success and motivation [12]. SNSs are therefore a potential method to remove such negativity [13].

The use of SNSs in education has many advantages. These are: increasing the quality of education through the use of computers; individualizing learning; being able to perform education and training independently from time and place [8]; increasing students' motivation; improving students' writing skills; involving students in the learning process [14]; enabling the students to reach knowledge [15]; making teacher-student communication easier [14] and making evaluation of education easier.

Although there are advantages of using SNS in education, there are also many disadvantages. Öztürk and Akgün [34] listed the disadvantages of the SASs in response to the answers they received from 659 students as a result of the questionnaire they applied: (1) they prevent socialization, (2) they have security risks, (3) they lead to role conflicts [40], (4) the grade average decreases, (5) there is too much content that is inappropriate for educational environments and (6) they are prohibited by many organizations.

In the distance education systems, TMSs and SNSs have been used to manage the learning environment, to share learning contents and to provide learner-learner, learner-teacher interaction and communication. However, the use of these two systems in education has different strengths and weaknesses. In this context, Educational Social Networking Sites (ESNS) have been developed, which aim to minimize the limitations of the both systems and include the superior aspects of both systems. Today, many ESNS are used. EDMODO, Ning, Elgg, Beyazpano and ValuePulse are among the most used ESNS.

In this study, Edmodo, the most popular ESNS, which defines itself as a social learning platform [16] and has more than 72 million users worldwide and resembles the most popular SNS, Facebook, was used. No matter how Edmodo is similar to Facebook, students can $\log$ in with the group code to the lessons the teachers have generated. In this case, security problems such as attending the lectures out of the teacher's control and using student information for different purposes have been reduced to the minimum [17]. Edmodo is a social learning platform in which teachers create and manage online classroom environments independently of time and space and students easily communicate with one another [18]. Edmodo, which was selected as one of the top 25 SNS by the American Association of School Librarians (AASL) in 2008, is also a good EMS at the same time. With this feature, teachers can communicate with students in the virtual environment, assign homework and collect the homework in the virtual environment, make quizzes about their lessons and create a questionnaire on a subject they want [19]. They can also easily share materials with its library feature [17]. It does not have features such as messaging between users, instant messaging and sending friend requests. Edmodo, separated from Facebook with this feature, has minimized the security problems that can arise from the communication between the students.

\section{Method}

This section includes the purpose of study, study design, study sample, data collection tools and analysis of data.

\subsection{The Purpose of the Study}

The purpose of this study is to examine Geography Department students' views on the use of Edmodo as an ESNS in course activities.

\subsection{The Method and the Design}

In this study, mixed methods research design was used. Mixed Research Methodology is a research method that has been developed by combining basic elements of qualitative and quantitative research approaches with the purpose of understanding and verifying the data in a deep and broader sense by research group or researcher [20]. The study was designed with sequential explanatory design among mixed methods research designs. In this design, the researcher supports the quantitative data obtained from the study with qualitative data. In other words, quantitative work is done first, and then qualitative method is employed to support data or findings obtained with quantitative work. In this study, quantitative data were obtained from the descriptive survey model in the first stage. Semi-structured 
interviews were then held with 10 randomly selected students to obtain their views so that quantitative data could be understood more clearly.

\subsection{Sample}

This study was conducted with a total of 41 second grade students taking Europe Geography class and studying in the Department of Geography in the Faculty of Science and Letters of İbrahim Çeçen University of Ağrı in the spring semester of 2016-2017. 15 of the participants are females and 26 of the participants are males. In the selection of the sample, taking the field studies class was determined as a criterion and the purposeful sampling method was used. The basic understanding in this sampling method was working with the ones who met predetermined criteria. In such studies, the criterion could be determined by the researcher or a previously determined criterion table could be used [21]. Although the study started with 41 participants, data could be collected from 37 participants. The data obtained from these 37 participants constituted the quantitative part of the study. For the qualitative part of the study, 10 participants were randomly selected from the 37 participants from whom data on the quantitative part was collected.

\subsection{Study Process}

The study is limited to a total of seven weeks, of which two weeks are pilot implementation and another five weeks are implementation period in spring semester of 2016-2017 academic year.

\subsection{Data Collection Tools}

The questionnaire prepared by Kazez and Bahçecik
(2016) was used to collect the quantitative data of the study. The items in the questionnaire were divided into three parts as usability, interaction / access to information and learning / feedback according to the most common problems encountered the learning process. Questions (1-10) among the items in the questionnaire included usability, (11-21) interaction / wisdom access, and (22-29) learning and feedback titles. The title of availability in the survey was created to get student views on the use of Edmodo features on computers and mobile devices. In the topic of interaction / access to information, there were elements that involved students' access to the documents, interactions within the classroom and outside the classroom, and in the topic of learning and feedback, the student has feedback on his / her homework, rewards, and feedback from the teacher.

In order to collect the qualitative data of the study and to support quantitative data, a semi-structured interview form was developed by the researchers as a result of the relevant field literature review. The semi-structured interview form was formed from a total of 6 open-ended questions consisting of 2 questions for each section to support the questionnaire sections.

\section{Findings}

\subsection{Opinions Geography Department Students about Edmodo's Usability}

The 1-10 items in the questionnaire were analyzed in order to take students' opinions on the use of Edmodo on desktop, laptop and mobile devices. The obtained findings are indicated in Table 1 as frequency, percentage and arithmetic mean.

Table 1. The views of the students on the use of Edmodo

\begin{tabular}{|c|c|c|c|c|c|c|c|c|c|c|c|}
\hline \multirow[t]{2}{*}{ The Questionnaire Items about the Usability of Edmodo } & \multicolumn{2}{|c|}{$\begin{array}{l}\text { Strongly } \\
\text { Disagree }\end{array}$} & \multicolumn{2}{|c|}{ Disagree } & \multicolumn{2}{|c|}{ Neither } & \multicolumn{2}{|c|}{ Agree } & \multicolumn{2}{|c|}{$\begin{array}{l}\text { Strongly } \\
\text { Agree }\end{array}$} & \multirow[t]{2}{*}{$\mathrm{X}_{\mathrm{i}}$} \\
\hline & $f$ & $\%$ & $f$ & $\%$ & $f$ & $\%$ & $f$ & $\%$ & $f$ & $\%$ & \\
\hline $\begin{array}{l}\text { 1. That the software has limited Turkish language support } \\
\text { has made its use difficult. }\end{array}$ & 2 & 5,6 & 6 & 16,7 & 3 & 8,3 & 21 & 58,3 & 4 & 11,1 & 2,47 \\
\hline $\begin{array}{l}\text { 2. The interface of the system was understandable and } \\
\text { easy. }\end{array}$ & 1 & 2,7 & 1 & 2,7 & 7 & 18,9 & 22 & 59,5 & 6 & 16,2 & 3,83 \\
\hline $\begin{array}{l}\text { 3. Mobile devices with small screens made the use of it } \\
\text { difficult. }\end{array}$ & 3 & 8,1 & 6 & 16,2 & 9 & 24,3 & 13 & 35,1 & 6 & 16,2 & 2,64 \\
\hline $\begin{array}{l}\text { 4. I had difficulty in sending homework through mobile } \\
\text { devices. }\end{array}$ & 5 & 13,5 & 10 & 27 & 1 & 2,7 & 18 & 48,6 & 3 & 8,1 & 3,10 \\
\hline $\begin{array}{l}\text { 5. I did not have difficulty in sharing status on mobile } \\
\text { devices. }\end{array}$ & 1 & 2,7 & 13 & 35,1 & 1 & 2,7 & 20 & 54,1 & 2 & 5,4 & 2,75 \\
\hline 6. I could easily comment on posts or my homework. & 2 & 5,4 & - & - & - & - & 23 & 62,2 & 12 & 32,4 & 4,21 \\
\hline $\begin{array}{l}\text { 7. I could easily access the course documents shared by } \\
\text { the teacher. }\end{array}$ & - & - & 2 & 5,4 & 1 & 2,7 & 22 & 59,5 & 12 & 32,4 & 4,18 \\
\hline $\begin{array}{l}\text { 8. I did not have any difficulty in the steps when I } \\
\text { registered Edmodo. }\end{array}$ & 2 & 5,4 & 3 & 8,1 & 2 & 5,4 & 22 & 59,5 & 8 & 21,6 & 3,83 \\
\hline 9. I did not have difficulty with Edmodo site use. & 1 & 2,7 & 7 & 18,9 & 6 & 16,2 & 17 & 45,9 & 6 & 16,2 & 3,54 \\
\hline $\begin{array}{l}\text { 10. I did not have any problems while uploading } \\
\text { homework to Edmodo in computer environment. }\end{array}$ & 1 & 2,7 & 6 & 16,2 & 5 & 13,5 & 15 & 40,5 & 10 & 27 & 3,72 \\
\hline
\end{tabular}


When Table 1 is examined, it is seen that the participants stated that they did not have any difficulty in using Edmodo site in computer environments. However, it was determined that they had problems in some applications on mobile devices but not in some others. For example, 56.7\% of participants stated that they had difficulty in sending homework on mobile devices, while $59.5 \%$ stated that they had no difficulty in sharing status on mobile devices.

According to the results of the interviews made in this subject, examples of students who did not have a great difficulty while using the program are given below.

K1 "I did not encounter any difficulties when using Edmodo"

E4 "Yes, I was very pleased because it was easier for me to hand over the assignments I prepared to the teacher"

$75.7 \%$ of the participants indicated that the interface of the Edmodo site was understandable and easy, and that they did not encounter any difficulty in using the Edmodo site. It is also seen that the participants stated that it was easy and understandable to upload, comment, sign up, and access the course documents in the computer environment. It is seen that $91.9 \%$ of the participants stated that they could easily access the course documents shared by the teacher.

E3 "It contributes to the teaching of the course because we have the chance to see many different ideas together and also contribute to the personal development as we write our thoughts."

E2 "It is also a good network because of the teacher's ability to send materials to us and obtain those materials."
As it can be understood from the sample expressions of the students, the sharing of documents and other materials is welcomed positively by the students.

Another remarkable finding about the usability of Edmodo is that Edmodo site's limited language support has made it difficult for students to use it. $69.4 \%$ of the participants stated that it was difficult to use the site because of the limit of language support.

E2 "I do not like these aspects as it has a completely English interface when I downloaded it to my phone, the program is slower, and the English words are intense even in the computer environment."

E3 "It would have been nice if the program was not in English when downloaded to the phone or if we get notifications when the manager sends a new message or assignment"

As the students have stated, having the English words makes it difficult to use this program.

\subsection{Opinions of the Geography Department Students about Edmodo's Interaction / Access to information}

In this section, the 11-21 items in the questionnaire were analyzed in order to determine the opinions of the participants on interaction and access to information features of Edmodo, and the obtained findings are indicated as frequency, percentage and arithmetic mean in Table 2 .

Table 1. The views of the students about the interaction and access to information features of Edmodo

\begin{tabular}{|c|c|c|c|c|c|c|c|c|c|c|c|}
\hline \multirow{2}{*}{$\begin{array}{l}\text { The Questionnaire Items About Edmodo's Interaction / } \\
\text { Access to information }\end{array}$} & \multicolumn{2}{|c|}{$\begin{array}{l}\text { Strongly } \\
\text { Disagree }\end{array}$} & \multicolumn{2}{|c|}{ Disagree } & \multicolumn{2}{|c|}{ Neither } & \multicolumn{2}{|c|}{ Agree } & \multicolumn{2}{|c|}{$\begin{array}{l}\text { Strongly } \\
\text { Agree }\end{array}$} & \multirow{2}{*}{$\mathrm{X}_{\mathrm{i}}$} \\
\hline & $f$ & $\%$ & $f$ & $\%$ & $f$ & $\%$ & $f$ & $\%$ & $f$ & $\%$ & \\
\hline $\begin{array}{l}\text { 11. Edmodo's announcements and notes features made it } \\
\text { easier to follow classes over Edmodo on days I could not } \\
\text { attend to classes. }\end{array}$ & 6 & 16,7 & 1 & 2,8 & 4 & 8,3 & 3 & 8,3 & 23 & 63,9 & 3,81 \\
\hline $\begin{array}{l}\text { 12. Instead of Edmodo, I would prefer to follow the } \\
\text { homework and course materials on paper. }\end{array}$ & 9 & 22,2 & 18 & 50 & 4 & 11,1 & 3 & 8,3 & 3 & 8,3 & 372 \\
\hline $\begin{array}{l}\text { 13. Edmodo increased participation in lectures compared } \\
\text { to traditional lectures. }\end{array}$ & 1 & 2,8 & 2 & 5,6 & 9 & 25 & 17 & 47,2 & 8 & 19,4 & 3,78 \\
\hline $\begin{array}{l}\text { 14. It made me feel uncomfortable that my friends saw the } \\
\text { comments I made. }\end{array}$ & 10 & 25 & 24 & 66,7 & 2 & 5,6 & - & - & 1 & 2,8 & 4,13 \\
\hline 15. I asked my friends for help when I had problems. & 1 & 2,8 & 4 & 11,1 & - & - & 22 & 58,3 & 10 & 27,8 & 3,97 \\
\hline 16. Edmodo improved communication with my friends. & 2 & 5,6 & 4 & 11,1 & 10 & 27,8 & 15 & 38,9 & 6 & 16,7 & 3,51 \\
\hline $\begin{array}{l}\text { 17. Edmodo improved my communication with the } \\
\text { teacher. }\end{array}$ & - & - & 2 & 5,6 & 8 & 19,4 & 16 & 44,4 & 11 & 30,6 & 3,97 \\
\hline 18. Using Edmodo reduced our interclass interaction. & 9 & 25 & 19 & 50 & 7 & 19,4 & 2 & 5,6 & - & - & 3,94 \\
\hline $\begin{array}{l}\text { 19. I think that the content of the lessons in Edmodo saved } \\
\text { time and labor. }\end{array}$ & 2 & 5,6 & - & - & 1 & 2,8 & 20 & 52,8 & 14 & 38,9 & 4,18 \\
\hline 20. I wanted to learn how to use Edmodo more effectively. & 2 & 5,6 & - & - & - & - & 24 & 63,9 & 11 & 30,6 & 4,13 \\
\hline $\begin{array}{l}\text { 21. It made me feel independent to write what I thought } \\
\text { about the homework. }\end{array}$ & 2 & 5,6 & 2 & 5,6 & 3 & 8,3 & 18 & 47,2 & 12 & 33,3 & 3,97 \\
\hline
\end{tabular}


As seen in Table 2, Edmodo site facilitates lesson following, lesson attendance and student-student interaction, student-teacher interaction and student-interface. The majority of participants noted that the Edmodo site facilitated the follow-up of the lesson. In item $11,72.1 \%$ of the participants stated that Edmodo facilitated the follow-up of lessons through Edmodo thanks to the announcements and notes features while in item 12 it was seen that $72,2 \%$ of the participants preferred to follow the course assignments via Edmodo instead of following with printed materials. There is emphasis on this situation in student opinions.

K1 "What I like most about Edmodo is that everyone can express his / her opinions easily and learn something about the information they share with other people."

E4 "My favorite feature is that I can deliver the homework to the teacher at any time and it is easier to exchange information with my friends. At the same time, I can express my opinion and thoughts about the subjects at any time. I can ask questions that occupy my mind to my friends directly here and they can express their own thoughts."

One notable finding in this section is that the Edmodo is seen as beneficial by the participants at the point of interaction. Items 15, 16, 17 and 18 in the questionnaire are for determining the effects of Edmodo in terms of interaction. When the relevant items were examined, it is seen in item 15 that $86.1 \%$ of participants stated that they asked for help from their friends at any difficulty. This is an indication of the communication with their friends. $75 \%$ positive response to Edmodo increased my interaction with my friends in item 16 can be seen as a finding supporting that Edmodo increased the student-student communication and interaction. In addition, $75 \%$ of the participants stated that it increased the communication with the teacher, and $75 \%$ of the participants stated that it increased in-class interaction.

The items 13-20 in the questionnaire are the items to determine effects of Edmodo in terms of participation. On analyzing these items, it can be seen that $66,6 \%$ of the participants stated in the item 13 that Edmodo increased attendance to the classes, in item 2094,5 of the participants stated that they want to use Edmodo more effectively.

\subsection{Opinions of the Geography Department Students about Edmodo's Learning and Feedback}

In this section, the items 22-29 in the questionnaire were analyzed in order to determine the opinions of the participants on learning and feedback features of Edmodo, and the obtained findings are indicated as frequency, percentage and arithmetic mean in Table 3.

As seen in Table 3, when the questionnaire items on Edmodo's learning and feedback were examined, it was seen that these items were gathered under the title of student responsibility, motivation and access to information. When questionnaire items were examined in general, it was seen that Edmodo increased student responsibility, increased motivation, and facilitated students at the point of access to information. Similar expressions were found in student views.

E2 "Because it is a certain period of time, it creates the feeling of doing homework on time. It is also a good network because of the opportunity for the teacher to send materials to us and to get those materials."

$\mathrm{K} 3$ "It accelerates the information exchange during the classes and improves the feeling of responsibility."

Table 2. The views of the students about the learning and feedback features of Edmodo

\begin{tabular}{|c|c|c|c|c|c|c|c|c|c|c|c|}
\hline \multirow{2}{*}{$\begin{array}{l}\text { The Questionnaire Items about Edmodo's Learning and } \\
\text { Feedback Features }\end{array}$} & \multicolumn{2}{|c|}{$\begin{array}{l}\text { Strongly } \\
\text { Disagree }\end{array}$} & \multicolumn{2}{|c|}{ Disagree } & \multicolumn{2}{|c|}{ Neither } & \multicolumn{2}{|c|}{ Agree } & \multicolumn{2}{|c|}{$\begin{array}{l}\text { Strongly } \\
\text { Agree }\end{array}$} & \multirow{2}{*}{$\mathrm{X}_{\mathrm{i}}$} \\
\hline & $f$ & $\%$ & $f$ & $\%$ & $f$ & $\%$ & $f$ & $\%$ & $f$ & $\%$ & \\
\hline $\begin{array}{l}\text { 22. Uploading assignments within a certain period has } \\
\text { increased my accountability to the course. }\end{array}$ & - & - & 2 & 5,4 & 3 & 8,1 & 16 & 43,2 & 16 & 43,2 & 4,24 \\
\hline $\begin{array}{l}\text { 23. The feedback / grades I received on the homework } \\
\text { increased my desire for the course. }\end{array}$ & - & - & 2 & 5,4 & 3 & 8,1 & 18 & 48,6 & 14 & 37,8 & 4,18 \\
\hline $\begin{array}{l}\text { 24. The teacher's comments and emojis / reactions for the } \\
\text { assignments increased my motivation. }\end{array}$ & - & - & 3 & 8,1 & 6 & 16,2 & 19 & 51,4 & 9 & 24,3 & 3,91 \\
\hline $\begin{array}{l}\text { 25. Its ability to save the homework I did made it easier for } \\
\text { me to reach my homework later. }\end{array}$ & - & - & 1 & 2,7 & 2 & 5,4 & 19 & 51,4 & 15 & 40,5 & 4,29 \\
\hline $\begin{array}{l}\text { 26. Talking and commenting on my homework prompted } \\
\text { me to do better homework. }\end{array}$ & 1 & 2,7 & 1 & 2,7 & 3 & 8,1 & 16 & 43,2 & 16 & 43,2 & 4,21 \\
\hline $\begin{array}{l}\text { 27. I believe that Edmodo has improved my academic } \\
\text { achievement. }\end{array}$ & 2 & 5,4 & 1 & 2,7 & 6 & 16,2 & 21 & 56,8 & 7 & 18,9 & 3,81 \\
\hline $\begin{array}{l}\text { 28. It helps students take responsibility for their own } \\
\text { learning. }\end{array}$ & 1 & 2,8 & 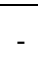 & - & 2 & 5,6 & 19 & 52,8 & 14 & 38,9 & 4,25 \\
\hline $\begin{array}{l}\text { 29. Teaching the courses on Edmodo provides continuous } \\
\text { assessment of the course. }\end{array}$ & - & - & 1 & 2,7 & 3 & 8,1 & 23 & 62,2 & 10 & 27 & 4,13 \\
\hline
\end{tabular}


When the items 22, 28 and 29 in the questionnaire were analyzed, $86.4 \%$ of the participants stated in item 22 that the determination of the duration of homework increased their responsibilities, $91.7 \%$ of them reported in item 28 that it increased their own learning responsibilities. In item $29,87.2 \%$ of the participants stated that Edmodo provided continuous evaluation of the lessons. When the opinions of the participants on this article were analyzed in depth, it was seen that this situation is effective in increasing their responsibility.

There are expressions that can be considered as examples of these findings from the interview results obtained from the students.

K3"You can deliver your homework on time; there is a certain date, and since it is not accepted after that date. It develops responsibility and it uses various visual elements and provides knowledge to be permanent."

K4 "In Edmodo, we are given a specific time, then we deliver our homework, and in any case when we cannot reach our teacher, we can send it out through the site."

E1 "It enables us to do our homework on time and be active. It ensures that we make use of time well and we have responsibility. The whole class does and sends their homework within a certain period of time and writes different information and ideas and we learn new things from each other. We all see and learn from each other's ideas.”

When 23, 24, 25 and 26 items were examined, it was seen that those were the items to determine the effects of Edmodo on student motivation. When these items were analyzed, it was seen that $86.4 \%$ of the participants stated in item 23 that the feedback given to the homework increased their interest, $74.7 \%$ of them stated in item 24 that the fact that the teacher leave comments and expressions on the homework increased the motivation. In addition, it can be said when the item 25 and 26 were examined, it was easy to reach the homework on the Edmodo and it prompts the students to prepare better homework.

One of the students who stated his opinions on their motivations for the course stated that it also made a contribution to their personal development.

E3 "It contributes to the teaching of the course because we have a chance to see different ideas altogether. It also contributes to our personal development as we write down our thoughts."

K4 "I see what my friends write and think about a subject, share their knowledge and I understand their different thoughts."

A notable finding in this section is that despite nothing was done to determine the academic achievement of the students in the study, they have indicated that their academic success was enhanced by the Edmodo. It can be seen in item 27 that $75.7 \%$ of the participants believed that Edmodo improved their academic achievement.

\section{Results and Discussion}

Within the scope of European Geography class which is the second-year course of Geography Department of Faculty of Science and Letters, difficulties are faced, such as following students' performances, controlling their homework, sharing the documents related to the lesson and interaction problems inside and outside the classroom. The views of the students of the geography department on the educational social networking platform used to solve the difficulties mentioned in this study were examined. A questionnaire consisting of 29 questions with usability, interaction / access to information and feedback titles was used in the study. The results of the study are presented in the direction of these titles, respectively.

After looking at the results obtained for the usability of Edmodo, it was determined that Edmodo is useful in computer environment, but mobile systems have some difficulties in some applications. After examining the difficulties encountered, it was determined that students have difficulties especially in uploading homework. The reason for this can be that it is difficult to transfer the homework prepared in the computer environment to the mobile environment. After analyzing the literature, it has been found that using Edmodo on mobile environment causes difficulties. However, the results obtained through the study show that there are problems in different points. For instance, in the study conducted by [22], it was determined that Edmodo's mobile application is small-screen, and slow internet speed does not meet the needs of the students, which are reported as difficulties by the students. It was determined that the interface of the system is easy and clear, and the students did not have any problems when using it. That the Edmodo's interface is similar to the one of Facebook, which is a popular SNS and therefore it creates a feeling of familiarity in students explain this $[23 ; 24 ; 25 ; 26 ; 27 ; 4]$. [23], for example, have found that as both the interface and functionality of the Edmodo platform are similar to Facebook, and the students are familiar with Facebook, they did not have any problems. Another noteworthy result of Edmodo's usability is that students stated that Edmodo has limited Turkish language support. After the literature is examined, it is seen that language support is mentioned as a problem in almost all the studies conducted in Turkey $[24 ; 25 ; 17 ; 26 ; 27 ; 28]$. However, this is not reported to be a problem in the studies conducted abroad.

When the findings about Edmodo's effects on classroom interaction and extracurricular activities are examined, it was determined that it increases interclass student-student interaction. This result which coincides with many results in the literature $[17 ; 24 ; 25 ; 26 ; 19]$ can be explained by the fact that the students get help from their friends in relation to the problems they encounter, and they can communicate with each other on this occasion. For example, [17] stated in their study that they students were helping each other in 
the problems they faced. It was seen that during the days when students could not attend classes, they followed the lesson through Edmodo and so they did not drift away from the classes. It was also determined that students stated that Edmodo is useful in communicating with the instructor. This result is parallel with the results in the literature [18; $19 ; 24]$. It was determined that although the students considered Edmodo as useful as a means of communicating with teachers, they considered the fact that it does not have instant messaging feature as a problem, and they stated that developing such a feature would be more beneficial. This result is similar to the results of many studies in the literature $[17 ; 24 ; 25]$. Another remarkable result in this section is that students want to use Edmodo more effectively.

Finally, it was determined that when Edmodo was used for learning and feedback, it raised student motivation, increased responsibility for lessons, and facilitated students to access information. It can be said that determining the duration of the homework by the teacher in homework activity over Edmodo and giving feedbacks through the badges and comments on the homework are effective in increasing student motivation. This result coincides with many studies $[24 ; 25 ; 26 ; 27]$. This shows that the students like the homework feature of Edmodo. Çankaya et al. [24] found out that the homework feature of Edmodo is one of the most admired features. Another important result of this section is that although there is nothing done to determine student academic achievement in the study, students believe that their academic success is enhanced by the Edmodo. This result is parallel to Özkan [25] study on Edmodo's effect on the student's academic achievement.

The study was conducted with the students of the Geography Department. However, when the literature is examined, it is seen that many studies are carried out with computer teacher students $[17 ; 26]$. The usefulness of Edmodo in these studies can be attributed to the fact that the studies were always carried out with students using such systems. However, since this study is conducted with students who did not use systems like Edmodo before, it is seen that the finding that Edmodo is a useful system is a more healthy result. It can be recommended to study the usability of Edmodo in different areas and branches by using this study which we think will contribute to the studies. It is also thought that the use of Edmodo and its effects on learning can be analyzed in depth if studies with more crowded study groups and long-term studies, and quantitative and qualitative data are used together. Conducting such studies is recommended to researchers.

\section{REFERENCES}

[1] S. Yıldırım, Sanal Dünya ve Web Temelli Öğrenme Ortamlarının Öğrencilerin Akademik Başarıları,
Motivasyonları ve Sosyal Bulunuşlukları Açısından Karşılaştırılması, Ankara: Gazi Üniversitesi Eğitim Bilimleri Enstitüsü, 2012.

[2] N. Duran, A. Önal ve C. Kurtuluş, «E-Öğrenme ve Kurumsal Eğitimde Yeni Yaklaşım Öğrenim Yönetim Sistemleri» içinde Akademik BiliĢim Konferansları 2006, Denizli, 2008.

[3] D. Kern ve M. Baldissera, «Moodle or Facebook? An Experience with Moodle UFRGS LMS in the Teaching of Art History, Theory and Criticism at Graduate Level» içinde International Conference: The Future of Education, 2012.

[4] D. M. Boyd ve N. B. Ellison, «Social Network Sites: Definition, History, and Scholarship» Journal of Computer-Mediated Communication, cilt 13, no. 1, pp. 210-230, 2007.

[5] M. T. Shier, «The way technology changes how we do what we do» New Directions for Student Services, cilt 2005, no. 112, pp. 77-87, 2005.

[6] F. H. Odabaşı, Ö. Mısırlı, S. Günüç, Z. Ş. Timar, M. Ersoy, S. Som, F. İ. Dönmez, T. Akçay ve O. Erol, «Eğitim için Yeni Bir Ortam: Twitter» Anadolu Journal of Educational Sciences International, cilt 2, no. 1, pp. 89-103, 2012.

[7] S. B. Kert ve A. Kert, «The Usage Potential of Social Network Sites for Educational Purposes» International Online Journal of Educational Sciences, cilt 2, no. 2, pp. 486-507, 2010.

[8] M. Ekici ve M. Kıyıc1, «Sosyal aglarin egitim baglaminda kullanimi» Usak Universitesi Sosyal Bilimler Dergisi, cilt 5, no. 2, pp. 156-167, 2012.

[9] K. P. Brady, L. B. Holcomb ve B. V. Smith, «The Use of Alternative Social Networking Sites in Higher Educational Settings: A Case Study of the E-Learning Benefits of Ning in Education» Journal of Interactive Online Learning, pp. 151-160, 2010.

[10] J. Westerlund, «Class size and student evaluations in Sweden» Education Economics, cilt 16, no. 1, pp. 19-28, 2008.

[11] G. Durak, S. Çankaya ve E. Yünkül, «Eğitimde Eğitsel Sosyal Ağ Kullanımı: Edmodo Örneği» Dumlupınar Üniversitesi Sosyal Bilimler Dergisi, pp. 309-316, 2015.

[12] E. C. Kokkelenberga, M. Dillon ve S. M. Christya, «The effects of class size on student grades at a public university» Economics of Education Review, cilt 27, no. 2, pp. 221-233, 2008.

[13] G. Miller, «Social Scientists Wade Into the Tweet Stream» Secience, cilt 333, pp. 1814-1815, 2011.

[14] H. Ajjan ve R. Hartshorne, «Investigating faculty decisions to adopt Web 2.0 technologies: Theory and empirical tests» The Internet and Higher Education, cilt 11, no. 2, pp. 71-80, 2008.

[15] M. K. Kabilan, N. Ahmad ve M. J. Z. Abidin, «Facebook: An online environment for learning of English in institutions of higher education?» The Internet and Higher Education, cilt 13, no. 4, pp. 179-187, 2010.

[16] Ocak 2017. «Edmodo» [Çevrimiçi]. Available: http://edmodo.com. 
[17] H. Kazez ve F. Bahçeci, «BÖTE Bölümü Öğretmen Adaylarının Edmodo Kullanımına Dair Görüşlerinin İncelenmesi» Eğitim ve Öğretim Araştırmaları Dergisi, cilt 5, no. 1, pp. 9-20, 2016.

[18] K. Balasubramanian, V. Jaykumar ve L. N. Fukeyb, «A Study on "Student Preference towards the Use of Edmodo as a Learning Platform to Create Responsible Learning Environment» Procedia - Social and Behavioral Sciences, cilt 144, pp. 416-422, 2014.

[19] C. Kongchan, «How a Non-Digital-Native Teacher Makes Use of Edmodo» içinde International Conference ICT for Language Learning, 5th Edition, Firenze, 2012.

[20] J. W. Creswell, Research design: Qualitative, quantitative, and mixed methods approaches, Sage publications, 2013.

[21] A. Yıldırım ve H. Şimşek, Sosyal bilimlerde nitel araştırma yöntemleri, Ankara: Seçkin Yayıncılık, 2013.

[22] F. Al-Kathiri, «Beyond the Classroom Walls: Edmodo in Saudi Secondary School EFL Instruction, Attitudes and Challenges» English Language Teaching, cilt 8, no. 1, pp. 189-204, 2015.

[23] C. Holland ve L. Y. Muilenburg, «Supporting Student Collaboration: Edmodo in the Classroom» içinde In Society for Information Technology \& Teacher Education International Conference, 2011.

[24] S. Çankaya, G. Durak ve E. Yünkül, «Using educational social networking sites in higher education: Edmodo through the lenses of undergraduate students» European Journal of Educational Technology,, cilt 1, no. 1, pp. 3-23, 2014.

[25] A. Özkan, Öğretim Elemanlarının Eğitsel Sosyal Ağ Kullanım Deneyimlerinin İncelenmesi: Edmodo Örneği, Erzurum: Atatürk Üniversitesi Eğitim Bilimleri Enstitüsü, 2017.

[26] F. Kılıçkaya, «Edmodo: Make your» içinde AATSEEL Newsletter, 2012.

[27] E. Ekmekçi, «Integrating Edmodo into Foreign Language Classes as an Assessment Tool» Participatory Educational Research, no. 1, pp. 1-11, 2016.

[28] F. Dewi, «EDMODO: ASocial Learning Platform for Blended Learning Class in Higher Education» Research in Education Technology: Pedagogy and Technology Journal, pp. 1-11, 2014.

[29] E. Alemdağ, «Edmodo: Eğitsel bir Çevrimiçi Sosyal
Öğrenme Ortamı» içinde XVIII. Türkiye'de İnternet Konferans1, 2013.

[30] M. Sarıkaya, «Öğretmen Adaylarının Edmodo Hakkındaki Görüșleri» içinde Conference: 8th International Computer \& Instructional Technologies Symposium, Edirne, 2014.

[31] E. Dere, Ü. A. Yücel ve S. Yalçınalp, «İlköğretim Öğrencilerinin Eğitsel Bir Çevrimiçi Sosyal Öğrenme Ortamı Olan Edmodo’ya İlişkin Görüşleri» Elementary Education Online, cilt 15, no. 3, pp. 804-819, 2016.

[32] K. S. Sanders, An examination of the academic networking site Edmodo on student engagement and responsible learning, University of South Carolina, 2012.

[33] Y. Beldarrain, «Distance Education Trends: Integrating new technologies to foster student interaction and collaboration» Distance Education, cilt 27, no. 2, pp. 139-153, 2007.

[34] M. Öztürk ve Ö. E. Akgün, «Üniversite Öğrencilerinin Sosyal Paylaşım Sitelerini Kullanma Amaçları ve $\mathrm{Bu}$ Sitelerin Eğitimlerinde Kullanılması ile İlgili Görüşleri» Sakarya University Journal of Education, cilt 2, no. 3, pp. 49-67, 2012.

[35] O. Polat, Eğitsel Sosyal Medya Platformları ve Edmodo Örnek Uygulaması, Konya: NECMETTĠN ERBAKAN ÜNG̈VERSĠTESĠ, 2016.

[36] T. Trust, «Motivation, Empowerment, and Innovation: Teachers' Beliefs About How Participating in the Edmodo Math Subject Community Shapes Teaching and Learning» Journal of Research on Technology in Education, cilt 49, no. 1-2, pp. 16-30, 2017.

[37] M. Thongmak, «Social Network System in Classroom: Antecedents of Edmodo (C) Adoption» Journal of e-Learning and Higher Education, cilt 2013, no. 1, pp. 1-15, 2013.

[38] J. M. Haefner ve J. Hanor, «iPads apps for utility and learning» içinde Proceedings of the 28th Annual Conference on Distance Teaching and Learning, 2012.

[39] T. Trust, «Professional Learning Networks Designed for Teacher Learning» Journal of Digital Learning in Teacher Education, cilt 28, no. 4, pp. 133-138, 2014.

[40] B. Warner ve J. Esposito, «What's Not in the Syllabus: Faculty Transformation, Role Modeling and Role Conflict in Immersion Service-Learning Courses» International Journal of Teaching and Learning in Higher Education, cilt 20, no. 3 , pp. 510-517, 2009.

\footnotetext{
${ }^{\mathrm{i}}$ This study was presented as an oral presentation at the congress titled "IVth International Eurasian Educational Research Congress".
} 